\title{
Melding Music and Poetry: Teaching German Art Song to English-Speaking College Students
}

\author{
Leslie Jones \\ Southeast Missouri State University, United States of America
}

\begin{abstract}
The study of German Art Song is a critical component of classical vocal music education. Undergraduate college students learn to perform songs in German, French, and Italian, as well as their native English. However, for many students, this becomes an exercise in memorizing random disjointed syllables and perhaps a few key words. Much of the depth of the interpretation is then lost, both to the student and to the audience. This paper offers an alternative approach, incorporating literary aspects of learning a song in German along with the strictly musical aspects. These musical aspects, such as pitches, rhythms, and musical phrases, are enhanced by knowledge of historical context, poetic form, rhyme, and interpretive possibilities. Together, a much more complete and meaningful performance is possible.
\end{abstract}

\section{Introduction}

Art song literature is a rich treasure, and these are a fundamental part of the education of an undergraduate music major. Art songs are generally defined as songs for one voice and piano accompaniment; the form takes two genres that are complete in themselves-music and words-and melds them into a new form that is valid in its own right. German art songs (Lieder) are perhaps the more prominent examples of this. The real flowering of the German Lied, as an important musical form, occurred in the early nineteenth century, as Romantic poetry and Romantic music came together. With earlier songs, music and poetry were often treated unequally, with one aspect taking precedence over the other. With the rise of the German Lied, words and music became partners, as did voice and piano. Thus, a new, holistic approach to the study and performance of these pieces was needed.

The typical process of learning an art song includes learning the pitches, the rhythms, and the words. However, those are only the first steps. Even when the words are in a singer $=\mathrm{s}$ native language, one seeks to communicate meaning, rather than simply a collection of words. This is even more important when singing in a different language, and understanding the historical context of the era also plays a role. Additionally, the piano part must also be examined, for it plays a vital role in this partnership. For our purposes here, we will use an art song by Robert Schumann (1810-1856) to illustrate a possible path to this goal. Our sample for this examination is ADer frohe Wandersmann@ (Opus 77, No. 1).

\section{Musical Mechanics}

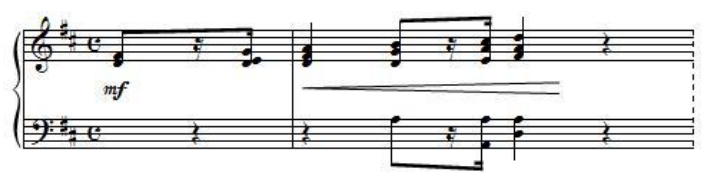

Figure 1. Beginning of song

First, the meter and basic rhythmic structure is examined. The metrical marking of Ac@ (common time, or 4/4) is equivalent to four beats per measure (the structure of the beats), and the rhythm (how those beats are divided and distributed in the measure) overlies that steady beat. A good practice when learning a new piece of music is to start with the rhythm, practicing it first with clapping the beats, then using a neutral syllable, such as Ata, @ to speak those rhythms. Our example is fairly straightforward, so this part of the process should be fairly simple.

Next, the key signature of two sharps, as well as the first few chords and the final chords, shows that the key of the piece is D Major. The melody moves smoothly along with steps from one pitch to the next consecutive one in the scale and with small intervals, or leaps.

The form is modified strophic: four similar verses, but unlike a hymn, the verses are not set exactly the same. One question the student should explore is why there are differences between the verses. Does the mood change? Is some important idea introduced? Does the composer's choice seem to support the text or even seemingly work against it, implying a different subtext? There are questions with no one correct answer, which leaves room for the performer's personal interpretation. 


\section{Language Considerations}

It is recommended to begin a study of the text even while still learning the basic musical notation. For singers, the International Phonetic Alphabet (IPA) is an invaluable tool. Study of the IPA allows the student to study which letters, and combinations of letters, create which sounds. Although there are slight differences between languages, there are enough similarities to promote a relatively understandable pronunciation from which to continue fine-tuning for a more idiomatic pronunciation. There are many helpful sources for IPA transcription, and with diction study, the student can arrive at a clear pronunciation. Using the natural accentuation of the text and the musical meter, one can easily determine the poetic stress of the text. The text for our art song (adapted by Schumann from Josef von Eichendorff $=\mathrm{s}$ poem), with stressed syllables in bold, is:

\section{Wem Gott will rechte Gunst erweisen, den schickt er in die weite Welt, dem will er seine Wunder weisen in Berg und Wald und Strom und Feld.}

Die Trägen, die zu Hause liegen, erquikket nicht das Morgenrot, sie wissen nur vom Kinderwiegen, von Sorgen, Last und Not um Brot.

Die Bächlein von den Bergen springen, die Lerchen schwirren hoch vor Lust, was sollt $=$ ich nicht mit ihnen singen aus voller Kehl $=$ und frischer Brust?

Den lieben Gott nur lass $=$ ich walten, der Bächlein, Lerchen, Wind und Feld, und Erd= und Himmel will erhalten, hat $\mathbf{a u c h}$ mein $=\mathbf{S a c h}=$ aufs Best $=$ bestellt .

With the unstressed-stressed pattern of syllables, the meter is primarily iambic. The rhyme scheme is also fairly regular, showing an $\mathrm{ABAB}$ ending rhyme for the words in each four-line strophe. Schumann=s setting of the text captures this perfectly, with strong syllables occurring on strong metric beats (beats one and three in common time).

A reliable word-for-word translation is another necessary step toward understanding the text and being able to communicate its meaning. Knowing the meaning of each word also helps the singer $=\mathrm{s}$ memorization work, since the text is no longer simply random syllables. However, most printed songs either do not include an English translation, or the one that is included is not very close to the actual meanings of the words (English singing versions, rather than actual translations). True word-for-word translations do not always appear logical, given the difference in word order between German and English, so re-phrasing the text for clarity, shown in parentheses here, is also helpful. Both are needed, however; a singer will sing the word "Liebe" differently knowing that it means "love" rather than "death". This excellent example of a complete translation comes from a commercial website, IPA Source, LLC [7]:

\section{1: Wem Gott will rechte Gunst erweisen, To-whom God wants true favor to-show, (When God wishes to show true favor to someone,)}

den schickt er in die weite Welt, him send $\mathrm{He}$ in the wide world, (He sends him out into the wide world)

dem will er seine Wunder weisen to-him will He His wonders show (to show him His wonders)

in Berg und Wald und Strom und Feld. in mountain and wood and river and field. (in the mountain, wood, river, and field.)

V. 2: Die Trägen, die zu Hause liegen, The lazy-ones, who at home lie, (The lazy ones who lie at home,)

erquikket nicht das Morgenrot, refreshes not the dawn, (are not refreshed by the dawn;)

sie wissen nur vom Kinderwiegen, they only know of children-rocking, (they only know about rocking babies,)

von Sorgen, Last und Not um Brot. of cares, burden and need and bread. (about cares, burden, need, and bread.)

V. 3: Die Bächlein von den Bergen springen, The little-brooks from the mountains spring, (The little brooks spring from the mountains,)

die Lerchen schwirren hoch vor Lust, the larks whir high for pleasure, (the larks soar high out of sheer pleasure,)

was sollt $=\mathrm{ich}$ nicht mit ihnen singen why should I not with them sing (why should I not sing with them) aus voller $\mathrm{Kehl}=$ und frischer Brust? from full throat and fresh breast? 
(with full throat and fresh spirit?)

V. 4: Den lieben Gott nur lass= ich walten, The dear God only let I reign/prevail, (I let God do his work;)

der Bächlein, Lerchen, Wind und Feld, the little-brook, larks, wood and field, (He sustains the brook, larks, wood and field,)

und Erd= und Himmel will erhalten, and earth and sky he-will preserve, (and earth and sky;)

hat auch mein $=$ Sach $=$ aufs Best $=$ bestellt. He-has also my matters for-the best ordered. (He has also ordered my life for the best.)

Here, we see typical German Romantic literature subject matter: the love of wandering and travel, the beauty and holiness of nature, and nature $=\mathrm{s}$ ability to connect us with God.

We return now to the straight-forward, marchlike melody and piano accompaniment, and see Schubert $=$ s use of painting the text with the music to show the footsteps of the wanderer.

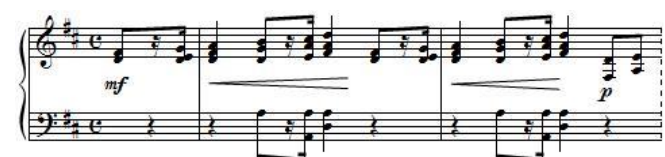

Figure 2. Text-painting example 1

Also, Schubert chooses a larger pitch interval in the vocal line at Aweite Welt@ to show us the Awide world.@

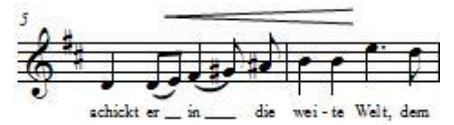

\section{Figure 3. Text-painting with melody}

Similarly, later on, ATrägen@ (lazy ones) is assigned a longer duration on the stressed syllable and a temporary switch to a minor key (Fig. 4), and the image of the larks flying high out of pleasure (Ahoch vor Luste) is shown again with a larger, ascending pitch interval (Figure 5).

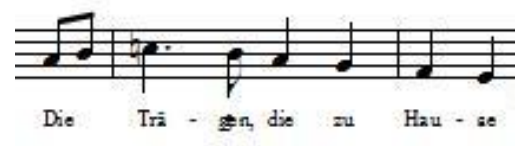

Figure 4. Text-painting with rhythm, key

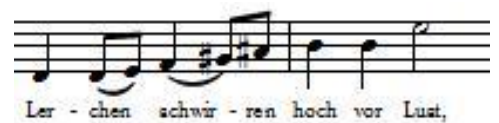

Figure 5. Text-painting with melody

One final example of this Atext-painting@ occurs in the last strophe (Figure 6), as the tempo slows (ritard.) at AErd= und Himmel will erhalten@ (earth and sky He will preserve).

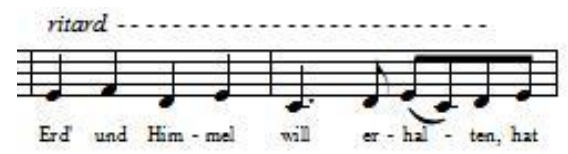

Figure 6. Text-painting with tempo

\section{Conclusion}

Armed with this knowledge and under the guidance of the teacher, the singer-student is now prepared to begin to integrate these elements into a rich, meaningful performance. This melding is not a quick process. The study of these aspects is best undertaken in comprehendible sections, lest the student become overwhelmed with the task. It takes time for all of these elements to become part of the performer and the song. The work involved in this process is immensely worthwhile. In the end, both the singer and the listeners are richly rewarded with a truly meaningful performance.

\section{Acknowledgements}

My colleagues in the Department of Music at Southeast Missouri State University continue to be a great source of support and inspiration. Special thanks are due to my colleague and friend, Dr. Gabriele Eckart, of the university's Department of Global Cultures and Languages for her instruction in the German language and her encouragement and guidance with this project.

\section{References}

[1] Emmons, Shirlee, and Wilbur Watkin Lewis. Researching the Song., Oxford, Oxford University Press, 2006.

[2] Fischer-Dieskau, Dietrich, George Bird and Richard Stokes, The Fischer-Dieskau Book of Lieder, New York, Limelight Editions, 1995.

[3] Glass, Beaumont, Selected Song Texts of Great German Lieder, Mt. Morris, New York, Leyerle Publications, 2004. 
[4] Kimball, Carol, Song: A Guide to Art Song Style and Literature, Rev. ed., Milwaukee, Hal Leonard Corporation, 2005.

[5] Miller, Philip L., The Ring of Words: An Anthology of Song Texts, New York, W.W. Norton \& Company, Ltd., 1973.

[6] Phillips, Lois, Lieder Line By Line, Oxford: Oxford University Press, 1996.

[7] Suverkrop, Bard (2009) "Der frohe Wandersmann", IPA Source, LLC; http://www.ipasource.com (6 May 2014). 